\title{
Polish Jokes about Americans
}

\author{
Dorota Brzozowska \\ Institute of Polish Language, University of Opole \\ ul. Oleska 48, 45-052 Opole, POLAND \\ dbrzozowska@uni.opole.pl
}

\begin{abstract}
The objective of the present paper is to analyze the character of Polish jokes about Americans and to find out what these jokes say about Poles. The latter question results from the assumption that stereotypes reveal more about those who propagate them than about those who allegedly represent particular traits. The popularity of Americans is a certain novelty in contemporary Polish jokes and this fact could be interpreted as another element in the processes of so-called McDonaldization.

The texts are presented by the chronology of events they refer to. Americans are perceived by Poles as the enemies of the Russians, and so as a positive protagonist, a symbol of the high standard of living and an embodiment of the dream of success and freedom. Wide open spaces and big American cities, cowboys, Indians, Hollywood and Coca Cola are other symbols frequently occurring in jokes. AIDS and drug addictions are also supposed to be the products of America altogether with American right to carry arms, litigiousness and death penalty. Another feature of the Americans readily exploited by scoffers is a relatively short history and the hypocrisy of American political correctness.

The general image of an American emerging from the analyzed jokes is largely positive and definitely more colorful than the image of a Pole in American jokes. Contextual references included in jokes show the knowledge of the Poles about America. And it does not really matter if this knowledge sometimes seems to be only a reflection of the image created and widespread by and for the use of the Americans themselves.
\end{abstract}

Nowadays, when the question of identity has become important once again and it is fashionable in many countries to create various types of "self-portraits", ${ }^{1}$ it seems necessary to closely examine texts which, sometimes ruthlessly, present our national traits. These texts are ethnic jokes - perfect benchmarks and carriers of the functioning stereotypes. Their condensed form holds the crux of the matter and shows, in a simplified and exaggerated, but also convincing way, the picture not just disregarding the principles of political correctness, but purposefully violating them. It has always been the main characteristic of jokes to break taboos and give vent to raising inappropriate or forbidden topics.

American jokes about Poles, so-called Polish jokes, which have even become the subject of scholarly research, have been classics of international humor for a long time. Generally, they are tasteless jokes presenting Poles as crude, stupid and dirty people. They reached the peak of popularity in the second half and at the end of the twentieth century. It can be interesting to study how Poles "pay Americans back" for this image. This paper's objective is the presentation of this issue or an attempt to answer the questions, "What are Polish jokes about Americans like?" and

\footnotetext{
${ }^{1}$ Cf. "Poles' Self-portrait" - Polish public TV program TVP S.A. http://www.ppw.com.pl
} 
"What do these jokes say about Poles?" The latter question results from the assumption that stereotypes reveal more about those who propagate them than about those who allegedly represent particular traits. Thus studying American jokes it is possible to learn a lot about Americans and their attitudes towards foreigners. Consequently, it can be concluded from Polish jokes what Poles find attractive or frightening in America, what amuses them the most and what they find worthy of admiration or denunciation.

Collections of jokes published in Poland in the past did not contain any significant number of jokes about Americans. Even if they functioned as individual texts, for some reasons they did not constitute a separate class strong enough to become an object of scholarly interest. Therefore, it is worth having a closer look at contemporary jokes in which the popularity of Americans is a certain novelty. It could be interpreted as a sign of the times or another element in the processes of globalization or so-called McDonaldization. So the presence of the American hero in Polish jokes is an element of a wider phenomenon which can be analyzed on a few levels. Firstly, such jokes are texts of a foreign origin which filter into the Polish culture. Because of the ever improving knowledge of English, especially among the younger generation, such jokes frequently circulate in their original versions. Thanks to the rapid flow of information, they are also quickly translated. ${ }^{2}$ Secondly, quite often they become an impulse for inventing local jokes - with some other or the same protagonists (e.g. jokes about blondes have been easily adapted in Poland). Thirdly, their popularity is habitually related to the current political events publicized by the media (it was so in the case of jokes about Clinton, the World Trade Center or the war in Iraq) which give rise to long series of jokes. And lastly, they are jokes which can be presumed to have been invented locally or jokes based on local reality, without many traces of their American origin, although they refer to America and its distinctive signs. This last group of jokes, which do not form any series, is the object of my special interest. I will present them taking into consideration the chronology of events they refer to.

At the beginning of the twentieth century and in the period between the world wars, large groups of Poles emigrated to America "in search of daily bread." ${ }^{3}$ Some texts with this topic can be found in The Encyclopedia of Polish Humor and Satire published in 1914. The entry Emigrant contains a humorous story entitled In America, and the entry America presents the following joke:

Nasi podróżnicy

- Otóż u nas w Ameryce jest znacznie inaczej.

- A czy pan był w Ameryce?

- Nie byłem tam nigdy, ale od lat kilkunastu, jestem własnym korespondentem amerykańskim jednej $\mathrm{z}$ tutejszych redakcji.

Encyklopedia humoru i satyry polskiej, red. A. Orłowski, Warszawa, Lwów, 1914.

Our travelers

- We in America live differently.

- But have you ever been to America?

- No, never, but for more than ten years I've been working for one of the local newspapers as their American correspondent.

\footnotetext{
${ }^{2}$ Cf. D. Brzozowska, Amerykanizacja dowcipów polskich [The Americanization of Polish Jokes], Stil, Belgrad [fortcoming].

3 "The really massive influx of over a million Poles into America occurred for economic reasons during the period between the American Civil War and the First World War with a peak of 140,000 Poles emigrating to America in the year 1913. [...] Chicago by 1914 was the home of 360,000 Poles and the third largest Polish city in the world" (Davies 2002: 163). In spite of the fact that a large number of Polish immigrants arrived to America in the years 1890-1914, there were no Polish jokes there (Davies 2004).
} 


\section{Dorota Brzozowska: Polish Jokes about Americans}

Poles emigrating across the Atlantic came mostly from the southern part of Poland ${ }^{4}$. Therefore, the folklore of the mountains and the flagship series of jokes "about the head shepherd" were permanently enriched with the plots concerning Poles in America, "good uncles" sending money to Poland, families left behind and those who had returned from America.

Mały Jasiek pyta mamę:

- Mamo, te nowe auto to od taty z Chicago?

- Och! Synku, gdybym liczyła na Twojego tatę, to ani auta bym nie miała, ani Ciebie, Jasiu. Super humor spod Giewontu, ed. S. Kałamacki, Zakopane n. y :7.

Little John asks his mother:

- Mom, the new car is from Dad, from Chicago?

- Oh, dear son! If I counted on your father, I'd have neither the car nor you.

Jokes presenting Poles' problems with communicating in a foreign language are especially popular:

Przyjechał baca do Ameryki i okradł bank. Siada w rowie przydrożnym, wyciąga z worka pieniądze i zaczyna liczyć. Nagle zjawia się przy nim amerykański funkcjonariusz i pokazuje służbową oznakę z napisem „Police”.

Na to baca:

- Dziękuję panoczku, sam se police.

M. Pinkwart, Z. Pytlik, Góralskie jaja. Mała antologia humoru góralskiego, Zakopane 2002: 99.

The head shepherd came to America and robbed a bank. He hides in a roadside ditch, takes notes out of the sack and starts counting. Suddenly he sees a uniformed official who shows him a badge saying "POLICE".

And the head shepherd says: - No, thanks for your help, mister. I can count it myself. [An untranslatable wordplay: "POLICE" in the Polish mountain dialect means "I will count".]

Although Americans are not one of the national types ridiculed in Komizm [The Comic] published in 1939, America is mentioned in the chapter presenting the influence of foreign languages on Polish. Bystron writes, "Of course, on the level of the permanent contact between Polish and English, i.e., among Polish emigrants in the USA, there develops a long series of such words which permanently enter the lexicon.[...] It suffices to read any Polish-American newspaper, whose editorial section is written in correct Polish, but whose classified ads contain a peculiar mixture of Polish and English words," e.g., stryt (street, "ulica'), tryn (train, 'pociag'), kara (car, 'automobil') (1939: 521).

In jokes referring to World War II, American protagonists appear occasionally in texts about the allied forces. They constitute a counterbalance to the German occupier and hope for the liberation of Poland.

Program gospodarczy na rok 1943: Roosevelt - orze, Churchill - sieje, Stalin - młóci, Hitler wieje...

Z. Jastrzębski, Poetyka humoru lat okupacji 1939-1944, Warszawa: PAX 1986.

The economic program for 1943: Roosevelt - plows, Churchill - sows, Stalin - threshes, Hitler winnows/cuts and runs [A wordplay in Polish: the verb "wiać" may mean "to winnow" or "to escape hurriedly".]

Rozmowa Niemców przez telefon:

- Jak to, nie wiesz, kto w tej wojnie zwycięży? - Die ACHSE (Oś).

- Nie rozumiem, mów głośniej.

- Przeliteruję: Ameryka, Chiny, Sowietrusland, England.

Zrozumiałeś? Z. Jastrzębski, Poetyka humoru lat okupacji 1939-1944, Warszawa: PAX 1986.

\footnotetext{
${ }^{4}$ The inhabitants of the western part of the country emigrated mostly to Germany.
} 
Two Germans talk on the phone:

- What do you mean you don't know who's gonna win this war? - Die ACHSE (The Axis).

- I can't hear you. Speak up.

- I'll spell it for you: America, China, Soviet Union, England. You got it?

W tym czasie, gdy ważyły się losy Stalingradu, Anglik, Amerykanin i Rosjanin toczą dyskusję nad tym, jakie jest największe miasto na świecie.

- Londyn, bo posiada siedem milionów mieszkańców.

- New York, bo ma dziesięć milionów.

- Stalingrad, - odpowiada Rosjanin - bo od przedmieścia idzie się ponad sto dni.

L. Buczkowski, Warszawski dowcip w walce 1939-1944, Warszawa 1947.

During the battle of Stalingrad, an Englishman, An American and a Russian discuss which is the biggest city in the world.

- London because it has seven million inhabitants.

- No, it's New York because ten million people live there.

- 'It's Stalingrad,' says the Russian, 'because it takes more than a hundred days to get from the outskirts to the center.'

The popularity of jokes about Americans started to grow after World War II. They appeared already in the period of the Stalinist regime when telling political jokes was subject to imprisonment:

- Wiesz, zbieram dowcipy o sobie - mówi prezydent USA do sekretarza generalnego KC PZPR.

- Ja też zbieram. A ile już masz?

- Ja mam cały zeszyt. A ty?

- A ja cały lagier.

Zakazany wic czyli polski dowcip polityczny 1944-1990, ed. W. Tocki, Łomżyński Tygodnik Społeczny „Kontakty” 1990: 31.

- You know, I collect jokes about myself - says the US president to the Secretary General of the Central Board of the Polish United Workers' Party.

- Oh, me too. And how many have you already got?

- I have the full notebook. And you?

- And I've got the full gulag [concentration camp].

Americans were perceived by Poles as the enemies of the Soviet "big brother." The constant attacks of the communist propaganda against the "imperialist" enemy resulted in enhancing the image of America as a positive protagonist, a symbol of the high standard of living and an embodiment of the dream of success and freedom. Thus Americans frequently appeared in jokes from the periods of the "cold war" and the "iron curtain", the "star wars", or the arms race.

Pomiędzy ambasadami USA i CCCP zorganizowano wymianę sekretarek. Po dwóch tygodniach amerykańska sekretarka pisze depeszę do swoich: "Moi drodzy, tu jest okropnie. Zero automatyzacji, ciaggle robię czaj szefowi, a spódnicę to dostałam taką długa, że ledwo chodzę."

W tym samym czasie wędruje depesza do Rosji:

"Moi drodzy, tu jest okropnie. Wszędzie te komputery, światełka, guziki, nie mam co robić, nudzę się. A spódnicę to mi dali taką krótką, że mi chyba widać jaja i kałasza." [http://tonybeta.w.interia.pl/39.htm $]^{5}$

There was an exchange of secretaries between the US and CCCP [Soviet] embassies. Two weeks later, the American secretary is typing a message to the Americans:

Dear Sirs,

\footnotetext{
${ }^{5}$ Some of the texts of the jokes downloaded from the web have been slightly adjusted [Editor's comment]
} 


\section{Dorota Brzozowska: Polish Jokes about Americans}

It's terrible here. No new technologies. I keep making tchai [tea] for my boss, and I got such a long skirt that I can hardly walk.

At the same time a message is being sent to Russia:

Dear Sirs,

It's terrible here. There are computers, lights, buttons all over the place and I have nothing to do. I

am getting bored. And they gave me such a short skirt that my balls and Kalashnikov may be seen.

Jokes frequently emphasized the technological and economic chasm between the competing superpowers. They revealed the deeply hidden truth about the countries of "bright socialism" which allegedly was a step towards an ideal social system: the progress of civilization was in fact much slower, and the living conditions were incomparably worse than in the countries of "bloodthirsty capitalism".

- Dlaczego kosmonauci radzieccy przebywają w kosmosie dłużej niż amerykańscy?

- A do czego się mają spieszyć.

Zakazany wic czyli polski dowcip polityczny 1944-1990, ed. W. Tocki, Łomżyński Tygodnik Społeczny „Kontakty” 1990: 68.

- Why are the Russian cosmonauts able to spend more time in space than the American ones?

- They have nothing to hurry back to.

One of the symbols of the American way of life was Coca Cola, which still remains an icon of American civilization. For many years of real socialism it could not be bought in Poland; in the best case it was substituted with Pepsi Cola produced for the markets of the socialist block.

Zdenerwowany szef zwiadu wbiega do szefa Centrum Lotów Kosmicznych NASA.

- Szefie! Ruskie na księżyc polecieli!

- Dobra, nic się nie dzieje.

Wyszedł. Za chwile przybiega znowu.

- Szefie! Oni malują księżyc na czerwono!

- Nic się nie dzieje - wyluzuj.

Wyszedł. Po pewnym czasie.

- Szefie! Oni już skończyli!

- Dobra, to teraz wyślijcie naszych, żeby napisali 'Coca Cola'.

[www.smirnof.isp.net.pl/html/archiwum_kawaly]

An irritated head of the scouts runs into the office of the head of the NASA's Space Flights Center.

- Boss! The Russians have gone to the moon!

- OK, take it easy, that's not a problem.

He leaves. A few minutes later, he gets into the room again.

- Boss, they have been painting the moon red!

- That's not a problem. Relax.

He leaves. A few minutes later:

- Boss! They have already finished!

- OK. Send our staff now to paint "Coca Cola".

Wide open spaces and big American cities, especially their awesome skyscrapers, are easily discernible and therefore frequently included in jokes.

Rabinowicz wyemigrował do USA. Po miesiącu dzwoni do żony z Nowego Jorku:

- Wszystko w porządku, znalazłem pracę. I bardzo blisko - niecałe pół godziny jazdy.

- Tramwajem?

- Nie, winda.

Humor polski, ed. A. Hącia, Warszawa: Świat Książki 2003: 122.

Rabinovich has immigrated to the USA. A month later he telephones his wife from New York: Everything is all right. I have found a job quite close to where I live - not even half an hour ... 
- By tramway?

- No, by elevator.

The United States is perceived stereotypically as the place where the "American dream" of a bootblack may come true, turning him into a millionaire:

Przed hotelem w Chicago siedzi smutny pucybut. Właściciel hotelu wychodzący właśnie na ulicę klepie go po ramieniu i mówi:

- Nie martw się, ja też zaczynałem jako pucybut, a teraz mam duży hotel. Taka jest Ameryka!

- Wcale się nie martwię. Kiedyś ten wielki hotel był mój, a teraz jestem zwykłym pucybutem. Taka jest Ameryka...

"Dobry Humor". O Amerykanach, 6/1999.

A sad bootblack sits in front of a hotel in Chicago. The hotel owner comes out to the street, taps him on the shoulder and says:

- Don't worry. I used to start as a bootblack as well and now I have this big hotel. This is America!

- I am not worried at all. I used to own this hotel and now I am a plain bootblack. This is America ...

Amerykański miliarder nagle zbladł, chwycił się za serce, przywołał swego sekretarza i mówi:

- Roger, to chyba zawał serca. Kup mi natychmiast jakiś dobry szpital.

"Dobry Humor". O Amerykanach, 6/1999.

An American billionaire suddenly gets pale; he touches his chest, calls his secretary and says: Roger, I am afraid it's a heart attack. Buy me a good hospital immediately .

In the communist times the Western was almost the only type of film circulated without much restriction. ${ }^{6}$ Therefore the strength of the stereotype identifying America with cowboys, Indians and Texas (teksas was even the name for Polish jeans) should not be surprising.

Rozmowa dwóch kowbojów:

- Widzisz tego blondyna, o tam?...- pyta Bill.

- Nie widzę.

Bill wyciaga pistolet i strzela.

- A teraz widzisz tego, co leży? Wczoraj ocalił mi życie.

Humor polski, ed. A. Hącia, Warszawa: Świat Książki 2003: 127.

Two cowboys are talking:

- Can you see the tall blonde man over there?...- asks Bill.

- No I can't. Bill pulls out a gun and shoots.

- And can you see him now lying on the ground? Yesterday he saved my life.

Młody Indianin w Arizonie obserwuje znaki dymne, za pomocą których porozumiewa się ze swoją narzeczona. Nagle na horyzoncie wyrasta ogromny grzyb po wybuchu jądrowym.

- Daj sobie spokój z tą dziewczyną- radzi mu stary i doświadczony Indianin. - To gaduła.

Humor polski, ed. A. Hącia, Warszawa: Świat Książki 2003: 123

A young Indian in Arizona is watching the smoke signs he uses for communicating with his girlfriend. Suddenly in the distance there appears a huge nuclear explosion mushroom cloud.

- Forget about the girl - an old and experienced Indian advises the young one. - She is a chatterbox.

\footnotetext{
${ }^{6}$ This topic had started to appear in satirical magazines much earlier. "Already at the end of the first decade of our [twentieth] century, thanks to the adventure stories by Karl May, the Western, which would become the passion of moviegoers in the 1940s, was present in popular literary magazines". T. Krzyżewski, Ksiega humoru lwowskiego. Teoria, dzieje i antologia humorystyki lwowskiej z lat 1800-1944 [The Book of Lvov Humor. The Theory, History and Anthology of Lvov humor 1800-1944] Warszawa: IWAR 1995: 177.
} 


\section{Dorota Brzozowska: Polish Jokes about Americans}

Such an image was created by the film productions of Hollywood, which itself is a symbol of America. It is characterized by its specific customs described in tabloids and popular women's magazines.

Podczas przyjęcia w Hollywood spotykają się dwie gwiazdy filmowe.

- O widzę, ze twój mąż zmienił uczesanie.

- Ależ nie! To ja zmieniłam męża.

"Dobry Humor". O Amerykanach, 6/1999.

Two film stars meet at a party in Hollywood.

- Oh, I see your husband has changed his hairstyle?

- No, it is me who has changed the husband.

Some other topics frequently raised by the media are the American right to carry arms, litigiousness and death penalty still in force in many states. They appear in numerous thrillers, court comedies or court dramas. Lawyers are popular as major characters not only in the novels of the most popular writers (e.g., J. Grisham) but also in a large number of typically American lawyers' jokes. This subjects are also present in jokes told in Poland:

W Teksasie do sklepu z bronią wpada kobieta:

- Poproszę rewolwer. Ma być nabity i niezawodny.

- Czy ma pani służyć do obrony?

- Nie, do obrony wezmę sobie adwokata.

Klub Masztalskiego, ed. A. Trzaska, t.1. 1000 dowcipów, Katowice: KAW 1989: 223.

A woman rushes into a gun shop in Texas.

- One revolver, please. Loaded and reliable.

- Are you going to use it to defend yourself?

- For defense I am going to use my lawyer.

W amerykańskim sądzie skazano oskarżonego na łączną karę130 lat więzienia. Sędzia pociesza go:

- Proszę się nie martwić, nie jesteśmy biurokratami. Odsiedzi pan tyle, ile będzie pan mógł.

„Dobry Humor”, O Amerykanach, 6/1999.

The defendant in an American court of justice is found guilty and gets a total verdict of 130 years in prison. The judge consoles him.

- You don't need to worry. We are not bureaucrats. You will stay in jail only as long as you can.

For many years the official propaganda claimed that all possible evil had its origin in the "rotten West". Even the plague of potato beetle was used for the purposes of the media "war against the imperialist enemy", who had allegedly used tons of insects as a biological weapon. Depravity, debauchery, corruption, AIDS and drug addictions were also the products of American intervention.

Rzecz dzieje się w Stanach. Polak przy odprawie celnej. Celnik mówi:

- Haszysz, marihuana, LSD...?

- Nie, dziękuję, ale napiłbym się chętnie herbaty...

Xięga Humoru, ed. D. Mondel, M. Skierkowski, Wrocław: FOX 1997: 306.

A custom officer asks a Pole during the customs control in the USA.

- Haszysz, marihuana, LSD?

- No, thanks, but a cup of tea would be nice.

Po odbyciu stosunku Amerykanka pyta partnera:

- Masz zaświadczenie, że nie jesteś chory na AIDS?

- Oczywiście, że mam! 
- No to możesz je podrzeć!

[http://bobo.fuw.edu.pl/ dgarm/txt/?(Dowcipy01)]

After having sex, an American woman asks her partner:

- Have you got a certificate that you aren't HIV positive?

- Of course, I have.

- So you can tear it into pieces now.

Another weakness of the Americans readily exploited by scoffers is a relatively short history of their state and a certain complex about Europe as the "old continent". Such sentiments and ignorance related to them are a rewarding topic for jokes.

Szkoła w Chicago. Nauczyciel historii opowiada uczniom o wojnach Rzymian z Żydami. Nagle mały John pyta:

- A po której stronie byli Amerykanie?

„Dobry Humor”. O Amerykanach, 6/1999.

A school in Chicago. A history teacher tells the students about the wars between Romans and Jews. Suddenly, little John asks:

- Which side were Americans on?

- Tutaj, moi panowie - mówi oprowadzający grupę Amerykanów przewodnik - widzimy średniowieczny zamek.

- Do jakiego filmu został zbudowany?

- Ależ szanowny panie, zamek pochodzi z XIV wieku!

- Co pan mówi? Już wtedy były kina?

Klub Masztalskiego, ed. A. Trzaska, t.1. 1000 dowcipów, Katowice: KAW 1989: 222.

- Here we can see a medieval castle - a guide says to a group of American tourists.

- What film was it built for?

- Dear Sir, the castle dates back to the $14^{\text {th }}$ century!

- You don't say! I didn't know they had cinemas back then!

Recently the hypocrisy of American political correctness - which started to rule also in the Polish media - has become the butt for ridicule:

Tratwa, płynie czterech rozbitków: Amerykanin, Polak, Rusek oraz Murzyn. Po pewnym czasie zaczęło kończyć się im jedzenie, więc postanowili wyrzucić Murzyna za burtę. Amerykanin doszedł jednak do wniosku, że to nie jest fair, więc wymyślił konkurs. Kto nie odpowie na pytanie ten wylatuje za burtę.

Amerykanin zadał pytanie Polakowi:

- Kiedy zrzucono bombę atomową na Nagasaki ?

- 1945r.

- Ok, Zostajesz.

Pytanie do Ruska:

- Ile osób zginęło ?

- 600 tysięcy.

- Ok, zostajesz.

Do Murzyna:

NAZWISKA! Szybko!

[http://www.smirnof.isp.net.pl/html/archiwum_kawaly]

There was a raft with four shipwrecked persons: an American, a Pole, a Russian and a Negro. After some time they were running out of food. Therefore, they decided to throw the Negro overboard. The American concluded that it was not fair and he invented a competition. The one who would not answer a question would be thrown overboard. Thus, the American asked the Pole:

- When was the atomic bomb dropped on Nagasaki? 
- In 1945 - OK.

- You will stay on board.

Another question was given to the Russian:

- How many people lost their lives?

- 'Six hundred thousands,' he answered.

- OK. You will stay onboard.

And the Negro was asked:

- 'NAMES! Quickly!'

In Polish jokes, Americans frequently appear in the company of characters representing other nationalities. During World War II they were the allies, in the period of the cold war - mostly Russians. Nowadays the pattern of nationalities in a group can be very diverse. It is interesting that in the traditional series of jokes about "a Pole, a Russian and a German" an American frequently takes over the position of a German.

Kanibale złapali 3 białych turystów: Ruskiego, Amerykanina i Polaka. Odbywa się rada plemienna, z którego co zrobią.

Rusek najgłośniej protestował, wiec długo nie myśląc przeznaczyli go na zupę.

Amerykanin chciał skontaktować się z konsulatem, więc go upiekli.

Polak milczal.

- A ty skąd jesteś? - zapytał wódz.

- Z Po.. Po.. z Polski.

- Polska! Tam studiuje mój syn! Bądź moim gościem bracie. Co będziesz jadł? Zupę czy mięso?

[http://home.elka.pw.edu.pl/ knowakow/zarty/polak]

Cannibals have captured 3 white tourists: a Russian, an American and a Pole.

They hold a tribe meeting on what meals they are to make out of them.

The Russian protests the loudest, so it doesn't take them long to make a soup of him. The American wants to contact his consulate - so they roast him.

The Pole keeps silent.

- And what about you? Where are you from? - asks the tribe chief.

- From Po..Po..Poland.

- Poland! My son studies there! Be my guest, brother. What would you like to eat - the soup or the roast meat?

To conclude, the importance of American motives in contemporary Polish jokes cannot be denied. The presence of Americans in this type of texts can prove the increasing importance of their image in the collective consciousness of Poles as fragmentarily reflected in the texts quoted above. It has to be admitted that the general image of an American emerging from the presented jokes is largely positive and definitely more colorful than the image of a Pole in American jokes. It also indicates a certain degree of familiarity with the reality of living in a particular society. In the case of Polish jokes, the opposite is the case. Their characters can be - and frequently are - substituted with the representatives of other nationalities. Using scripts which usually are not culturally embedded, ${ }^{7}$ Americans tell jokes about Poles not knowing much about them. Nevertheless, contextual references included in jokes about Americans indicate the knowledge of the Poles about America. And it does not matter if this knowledge sometimes seems to be only a reflection of the image created and widespread by and for the use of the Americans themselves.

\section{Literature}

Attardo S., 2001, Humorous Texts: A Semantic and Pragmatic Analysis. Humor Research 6. Berlin: Mouton de Gruyter. Bier J., 1988, The problem of the Polish joke in derogatory American humor. W: "Humor" 1-2, s. 135-141. Blanc C., A. Dundes, 1990, You Call this Living? A Collection of East European Political Jokes, Georgia. Bystroń J. S., wyd. 2. 1993, Komizm, Warszawa.

\footnotetext{
${ }^{7}$ As Davies remarked, these jokes do not contain any Polish words, with the exception of sporadically used names of dishes such as bigos or pierogi, which entered the English language as borrowings.
} 
Chłopicki W., Davies C., Dowcipy o Polakach w Ameryce - znamienny wytwór współczesnego społeczeństwa masowego, artykut udostęniony przez autorów.

Davies C., 2002, The Mirth of Nations, New Brunswick, London: Transaction Publishers.

Kurcz I., 1994, Zmienność i nieuchronność stereotypów. Studium na temat roli stereotypów w reprezentacji umysłowej świata społecznego. Warszawa: Instytut Psychologii PAN.

Paton G, C. Powell, S. Wagg, 1996, The Social Faces of Humour. Practices and Issues, Arena Ashgate

Publishing Limited England.

Raskin V., 1985, Semantic Mechanisms of Humor, Reidel Publishing Company. 